\title{
Economics and sustainable forest development: The case of soil degradation
}

\author{
by William A. White1
}

\begin{abstract}
Society's desire for greater emphasis on environmental quality is discussed within the context of the economics of soil degradation. The differences between production efficiency, financial efficiency and economic efficiency are demonstrated via the production possibility frontier. Forest products production is shown to decrease at least in the short term in the presence of forest harvest ground rules. Market forces will cause a portion of these losses to be regained.
\end{abstract}

\section{Résumé}

L'auteur parle du désir de la société à mettre l'accent davantage sur la qualité de l'environnement, en fonction des aspects économiques de la détérioration du sol. On illustre les distinctions qui existent entre la productivité, l'efficience financière et l'efficience économique en traçant la frontière du possible en ce qui concerne la production. On montre qu'à court terme du moins, la production devrait faiblir avec l'introduction de règles fondamentales sur l'exploitation forestière. Néanmoins, les forces du marché compenseront dans une certaine mesure les pertes enregistrées au niveau de la production.

\section{Introduction}

The forest sector is in a state of change. As Canada makes the transition from old growth to second- and even thirdgrowth stands, interest is keen in the quality and quantity of wood that will be available for future harvests. Canadians have also grasped the concept of sustainable development (World Commission on Environment and Development 1987) and desire future generations to continue enjoying similar benefits from Canada's vast forest resource.

Economists and the science of economics are often criticized for failing to keep pace with this change and for not having the tools to analyze questions involving sustainable development. This criticism often focuses on the economist's predisposition for financial analysis of onsite timber values while environmental values are given little attention. In reality, methodologies, such as cost benefit analysis, exist to analyze these problems and universities generally do a good job of teaching these techniques in both undergraduate and graduate level economics courses. Reliable data, however, on environmental and other non-timber values is difficult to obtain and this will need to be a focus of future interdisciplinary research.

Society's changing values have altered what constitutes economically efficient production in the forest sector. Adopting society's goal of sustainable development constrains the current technology available to the forest sector to maximize timber values today. It can be proven that financial analysis of the timber values alone fails to provide society with an economically efficient solution since it does not account for all the benefits of the forest. In addition, when the public's values are imposed on the forest sector operating on Crown land, financial analysis of timber values falls short of providing an efficient solution for the forest industry.

One aspect of the shift to a greater concern for environmental values that has recently attracted considerable attention in forestry circles is the impact on forest soils of harvesting and silviculture activities and their influence on the future productivity of the forest (Lousier 1990). While much effort has been spent in learning about the impacts of various activities on forest soils and more research is in progress

${ }^{1}$ Economist, Northern Forestry Centre, Forestry Canada. (particularly on the long-term impacts on site productivity) the economics of soil disturbance has received little attention. This makes soil disturbance an appropriate backdrop to investigate the economics/environment interface.

A goal of this paper is to show how economic forces affect forest industry decisions with respect to avoiding deleterious effects on the soil. Through this discussion it will also be shown that economics has the tools to effectively analyze problems involving issues such as sustainable development or environmental values by emphasizing the difference between financial analysis and efficiency, and the broader terms of economic analysis and efficiency. The next section of the paper reviews the economist's definition of efficiency within the context of production possibility frontiers. This will be followed by a section applying this definition to the case of detrimental soil disturbance and will include a review of the limited literature in the field of the economics of soil disturbance. The final section includes some concluding remarks.

\section{Economic Efficiency}

One need only spend a few minutes in an introductory economics class before the word scarcity is heard. The economist defines scarcity as simply wanting more than we have (Alchain and Allen 1983). No matter how well off we may be, our wants and goals will remain to some extent unfulfilled. The existence of scarcity implies that there is a limit to what society can produce and that the production of one good requires the sacrifice in production of another good. Economists portray this concept in a production possibilities frontier (Figure 1).

The line joining the axes represents the maximum achievable combination of goods A and B which can be produced. As a teaching tool, economists often place "guns" on one axis and "butter" on the other to portray the tradeoff between military goods and consumer goods. We can also portray the tradeoff between environmental values and forest product values in this way. Unless we are producing at a point inside the boundary curve, such as point $\mathrm{C}$, more of good A can be produced only if some production of good B is forgone. Points beyond the boundary curve, such as D, are not 


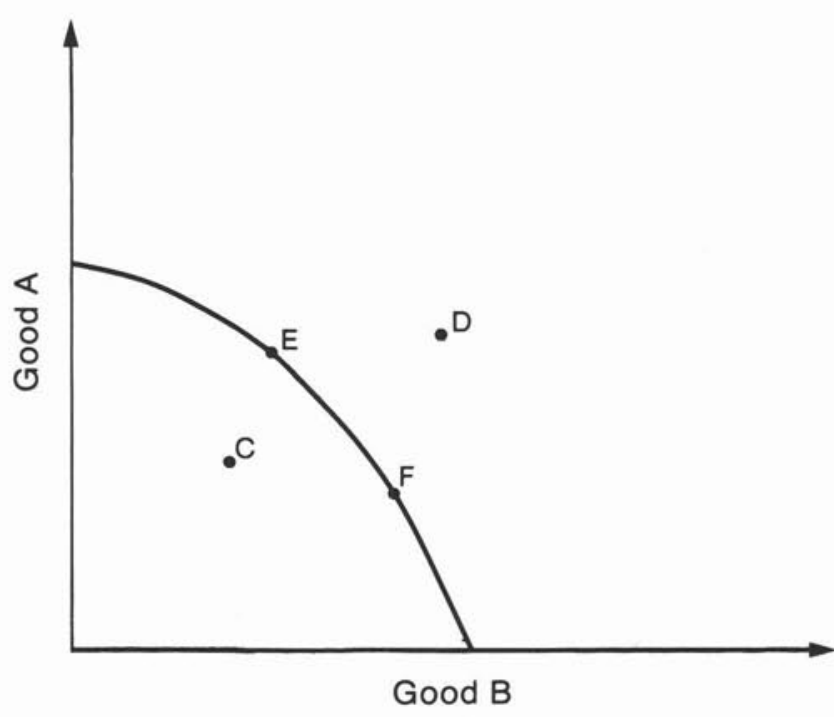

Figure 1. The production possibilities frontier.

attainable given current economic resources and technology. If an economy is producing a combination of goods that falls on the boundary curve, such as point $\mathrm{E}$ or $\mathrm{F}$, productive efficiency has been achieved. Since any point on the boundary curve is efficient, how do we choose between points such as $\mathrm{E}$ and $\mathrm{F}$ to determine which is the "best" combination of goods?

A criterion must be selected to rank or judge the goodness of each combination to decide which one is best. In market economies it is usually the price mechanism that determines the appropriate allocation of resources and the resulting best point on the production possibility frontier. When the price mechanism fails to provide a suitable resource allocation because there are too few actors (monopoly, cartels, etc.) or all costs are not borne by the decision maker (externalities) a situation called market failure exists (Rowley and Peacock 1975). Government intervention through regulation is often used to help determine the appropriate resource allocation in cases of market failure or other cases such as unacceptable income distribution. The criterion is largely but not exclusively normative and should reflect society's norms and values. One point on the boundary curve, whether determined by market forces, government intervention or some combination of the two, is defined as the economically efficient level of output.

Thus economic efficiency refers not only to a certain value or quantity of goods and services but also to an efficiently produced set of all goods and services in a "best" combination determined either by market forces or by those placed in a position to implement what society deems as "best". The economic definition of a good is very broad, encompassing anything that someone desires. Thus environmental benefits can be classified as goods and as part of the set of all goods and services that society will try to produce in an economically efficient manner.

Economic analysis goes far beyond simple financial analysis including whatever goods the decision maker wants in the decision set. To show how this set can include environmental variables the case of soil disturbance is discussed.

\section{The Economics of Soil Disturbance ${ }^{2}$}

The impact on forest soils of harvesting and silviculture activities has attracted considerable attention recently. This is particularly true in British Columbia where ground rules for harvesting aimed in part at conserving soil productivity for subsequent crops have recently been implemented and similar rules are being discussed for silviculture.

This concern stems from the detrimental impacts harvesting and silviculture activities can have on forest soils. Utzig and Walmsley (1988) estimated that, exclusive of haul roads, productivity on each hectare harvested and site-prepared declines by $10 \%$. The primary sources of these losses are mechanical soil displacement, compaction, puddling and soil erosion caused by elements of harvesting and site preparation such as landings, haul roads, bladed skidroads, heavily used skidtrails, backspar trails, fireguards, blade scarification, windrowing and piling gouges and deposits (Smith, Krag and Senyk 1989). Erosion and mass wasting can also cause considerable offsite damage.

Very little attention has been directed towards the economics of soil disturbance. One reason for this is the difficulty in obtaining appropriate data on the productivity impacts of soil disturbance, the values of offsite impacts and other pertinent information. Since no standard procedure for soil disturbance problems has been generally available, a variety of methods, most with a very narrow focus and some rather ad hoc, make up the small body of literature.

Klock (1976) shows that more expensive logging systems may be warranted when the costs of overcoming loss of site productivity and reservoir sedimentation are considered. Donnelly (1977) reaches a similar conclusion when road maintenance costs are considered over a number of treatment entries in the early life of the next stand. Bowden (1988) provides a general discussion on how an economist should approach the problem but is pessimistic about its resolution given existing data constraints and the difficulty of forecasting future values. A common thread in each of these papers, which is emphasized by Hammond (1988), is that holistic planning has the potential to be a cost-effective means to minimize soil disturbance impacts. Hammond estimates rehabilitation costs at $\$ 2500-\$ 4000 / \mathrm{ha}$ and planning costs at $\$ 200-\$ 400 /$ ha. Rice et al. (1985) and Sessions et al. (1987) in their discussions of landslides also emphasize pre-harvest planning.

Routledge (1988) shows that the private landowner has little financial incentive to maintain future site productivity. Bowden (1988) and Hickman and Jackson (1979) also make this point. Routledge extends his analysis to show that when a site is managed for maximum sustained yield, future rotations cannot be ignored and the incentive to take care of the land today increases. The results differ because under a sustained yield approach (which can be thought of as a subset of a sustainable development approach) future values are no longer discounted, or in other words trees tomorrow are given equal value to trees today. In a financial analysis this is equivalent to setting the discount rate to $0 \%$. The role of the discount rate is also emphasized in Routledge (1987) and

\footnotetext{
${ }^{2}$ Soil disturbance in this paper means detrimental soil disturbance. It is recognized that some activities that disturb the soil (such as scarification) are conducted for their beneficial effects of future rotations.
} 
Stewart et al. (1988). The latter use a net present value (NPV) analysis to determine the justifiable increased cost to eliminate the productivity effects of soil compaction. The impact of varying the site index is also studied.

Schwab (1988) and Utzig and Walmsley (1988) attempt to estimate gross losses incurred from soil disturbance. Although this may show the overall magnitude of the problem, the figures generated from such analyses are not useful by themselves to the economist. Future losses may be shown to be great, but that does not necessarily mean that it is financially or economically efficient to spend money to solve the problem today.

With the exception of Routledge (1988), the literature has focused on financial analyses with the emphasis on what one can afford to pay today to overcome the deleterious effects of soil disturbance. While the NPV financial studies are methodologically sound, they fall short in providing a framework for analyzing situations characterized by constraints imposed by society's desire for environmental safeguards and implemented through government policy. When the public's values diverge from market derived solutions, the economically efficient production point will vary from the financially efficient production point. The impact of government policies as a constraint on the decision making process is discussed below in the context of production possibility frontiers.

\section{Production Possibility Frontiers and Constrained Maximization}

The problem of detrimental soil disturbance can be demonstrated on a production possibilities frontier as shown in Figure 2. The horizontal axis represents forest product values attainable from the forest resource while the vertical axis represents onsite soil productivity and other environmental values (wildlife, water quality, etc.) both on and offsite. Points X and Y show levels of output for one or the other output if produced exclusively, while other points on the boundary curve depict efficient production combinations. The concave shape of the boundary curve characterizes diminishing returns or the increasing sacrifice or opportunity cost required to obtain the last unit of value. For instance, to obtain the last unit of forest product value one would harvest the most sensitive site and cause the greatest loss in environmental values. Conversely to obtain the last unit of environmental value one would sacrifice cutting an area highly suited to timber production with little risk of environmental damage.

Let us first investigate the case of a private operator on private land interested only in the financial aspects of the soil degradation question. Assume that he has no interest in offsite environmental values and operates in an unregulated setting that allows him to be concerned with only his own financial interest. ${ }^{3} \mathrm{He}$ owns a stand of trees and has decided to plant another stand on the site and his only question now is what harvesting system and site preparation operation should he undertake to maximize the NPV of the site. With offsite values being of little concern and losses in soil productivity not affecting the calculation until the next rotation, the

${ }^{3}$ Private operators certainly have goals that are not purely financial, such as passing productive sites on to future generations. The assumptions made here simplify the example and provide a contrast to the regulated setting discussed later in the paper. efficient point of production in these circumstances would be a point on the boundary curve near or on the horizontal axis. A decision to reduce soil disturbance today either through better pre-harvest planning or the use of a different harvest system, or to rehabilitate a damaged site would mean higher costs and thus lower net revenue today. These would have to be offset by the NPV of expected future revenues. As shown by Routledge (1988) and Bowden (1988) this is not likely to provide adequate incentive for the private operator to protect soil values.

Particularly in western Canada there are few private operators who can make decisions in this way. Most operators are more likely to be operating on Crown land without a guarantee of harvesting the next crop from the site they harvest today. In this case there is even less incentive for the operator to protect future site values. Current revenue can be maximized and since there is no guarantee of a future crop to pay for increased costs today, the financial incentive is not present to prevent detrimental soil disturbance. In the context of the production possibilities frontier, the economically efficient point of production will again approach the horizontal axis when resources are allocated through the price mechanism. This does not mean that all operators would leave a site in a deplorable state. Some in the name of good forestry or to enhance the value of the firm's name (goodwill) will allocate resources to protect soil productivity and other environmental values and accept the associated costs.

The point on the boundary curve chosen by the operator as economically efficient may not be in harmony with society's norms and values. Since the operator is on Crown land, society's values can be imposed through government regulation. The line $\mathrm{ZZ}$ ' in Figure 2 corresponds to a minimum level of environmental values that society is willing to accept. The economically efficient level of production is now constrained to be a point on the boundary curve above Z'. Moving up the boundary curve away from the original market determined point of economic efficiency (near Y) will have an effect on both the individual operators and on society as a whole. The decision that the operator now faces in light of increased costs is no longer "Do I want to preserve soil quality on this site?" as it was in the previous cases but rather "Do I want to log this site or not?"'. Future values no longer enter into the decision. Given existing technology at the time regulations are imposed, operators would certainly not find it financially feasible to log all the sites they would have logged in an unregulated setting. The move up the production possibility frontier means that the economic timber supply today will be reduced through efforts to preserve tomorrow's crop and/or minimize offsite damage. Sacrificing the benefits to society from the forest products forgone in favour of environmental values is the cost society chooses to pay. Since society has willingly chosen this tradeoff, the resulting output is deemed to be economically efficient.

Market forces will now move the operator to gain back at least a portion of the forest product values that have been taken from him. This will also be in society's interest as long as the level of post harvest soil productivity and other environmental values are retained. This can be shown on the production possibility frontier (Figure 2 ) by shifting the curve outward while keeping it anchored with the same endpoints. Now a greater level of forest products can be produced at each and every level of environmental values. In practical 


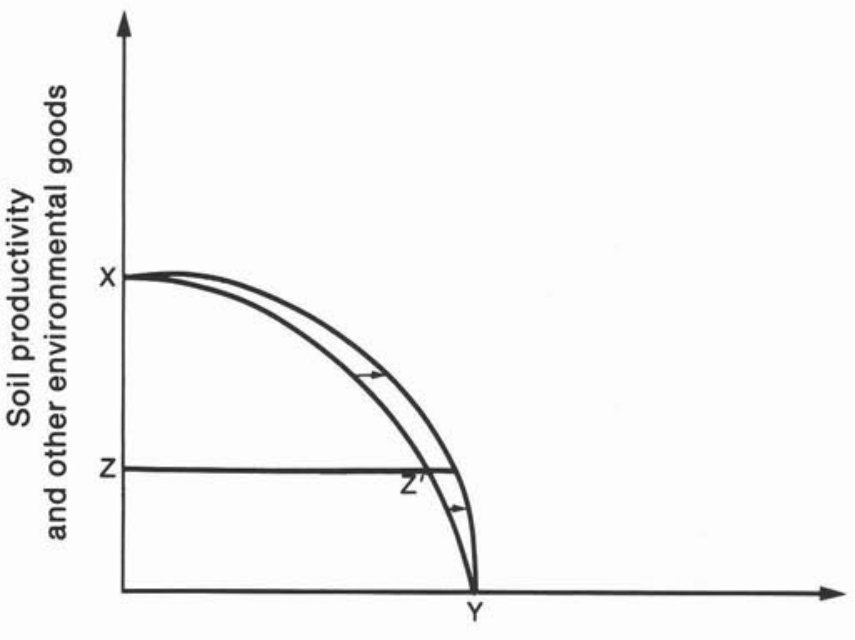

Forest products

Figure 2. Production possibility frontier for the forest resource.

terms this can be accomplished with modifications in technology. The financial incentives exists to create cost-effective harvesting systems that retain soil productivity and reduce offsite risks and thereby regain a portion of the economic timber supply. Developments in this area include a move to better planning of forestry operations (Hammond 1988), small rubber-tired and high flotation skidders of skidders equipped with wide low ground pressure tires and roads constructed and stumps removed with excavators rather than bulldozers (Smith, Krag and Senyk 1989).

Developments such as these can be viewed as a part of society's ongoing battle to overcome scarcity. In a world without scarcity, the production possibility frontier would be a vertical line rising from point $Y$. Society could have full forest product values and not be required to give up any environmental values. Given that this is not possible, efforts are continually being made to develop new technologies that will result in outward shifts of the boundary curve which will allow society to enjoy as much of both goods as possible.

\section{Conclusion}

Society's desire to have healthy forests for future generations is being met by both regulation and market forces. Government soil disturbance guidelines will ensure that future site productivity is maintained while market forces protect forest product values through new harvesting and site preparation technologies. The result should be an economically efficient balance between soil productivity and other environmental values and forest product values.

Ecomonics has been maligned for being silent on questions involving environmental values. This is partly because economic analysis is often confused with financial analysis. Problems involving tradeoffs such as wood products versus environmental values are questions of scarcity and limited production possibilities which are at the very core of economic analysis. Further research is needed to determine appropriate financial values for environmental goods. Economists should play a key role in developing these values.
A knowledge of environmental values would help society to evaluate more accurately the tradeoffs that are being made and will continue to be made between environmental values and forest product values.

\section{References}

Alchain, A.A. and W.R. Allen. 1983. Exchange and Production. Third Ed. Wadsworth Publishing Company. Belmont, California.

Bowden, G.K. 1988. Economics of forest soil degradation and rehabilitation. Pages 217-222 in J.D. Lousier and G. Still (eds.) Degradation of Forested Lands - Forest Soils at Risk. Proc. Tenth BC Soil Science Workshop. Land Management Report No. 56. BC Ministry of Forests, Victoria.

Donnelly, D.M. 1977. Estimating the least cost combination of cable yarding and tractor skidding for a timber sale area. USDA For. Serv. Res. Note RM-341. Mimeo 8 p.

Hammond, H.L. 1988. Soil degradation: costs of rehabilitation versus costs of prevention. Pages 227-237 in J.D. Lousier and G. Still (Ed.). Degradation of Forest Lands - Forest Soils at Risk. Proc. Tenth B.C. Soil Science Workshop. Land Manage. Rep. No. 56. BC Ministry of Forests, Victoria.

Klock, Glen O. 1976. Estimating two indirect logging costs caused by accelerated erosion. USDA Gen Tech Rep PNW-44 9 p.

Lousier, J.D. 1990. Impacts of forest harvesting and regeneration on forest sites. Land Manage Rep No. 67. BC Minist. For. Victoria.

Rice, R.M., N.H. Pillsbury and K.W. Schmidt. 1985. A risk analysis approach for using discriminant functions to manage logging related landslides on granitic terrain. For. Sci. 31: $772-784$.

Routledge, R.D. 1987. The impact of soil degradation on the present net worth of future timber harvests. For Sci. 33: 823-834.

Routledge, R.D. 1988. Assessing long-term costs of forest soil degradation. Pages 223-226 in J.D. Lousier and G. Still (eds.) Degradation of Forested Lands - Forest Soils at Risk. Proc. Tenth BC Soil Science Workshop. Land Manage. Rep. No. 56. BC Ministry of Forests, Victoria.

Rowley, C.K. and A.T. Peacock. 1975. Welfare Economics: A Liberal Restatement. Martin Robertson. London, England.

Schwab, J.W. 1988. Mass wasting impacts to forest land: forest management implications, Queen Charlotte timber supply area. Pages 104-115 in J.D. Lousier and G. Still (eds). Degradation of Forested Lands - Forest Soils at Risk. Proc. Tenth BC Soil Science Workshop. Land Manage. Rep. No. 56. BC Ministry of Forests, Victoria.

Sessions, J., J.C. Balcom and K. Boston. 1987. Road location and construction practices: effects on landslide frequency and size in the Oregon Coast Range. Western J. Appl. For. 2: 119-124.

Smith, R.B., R.K. Krag and J.P. Senyk. 1989. Soil disturbance and impacts on tree growth resulting from forestry operations in mountainous terrain. Paper presented at Seminar on the impact of mechanization of forest operations on the soil. September 11-15 1989, Louvain-la-Neuve, Belgium.

Stewart, R., H. Froehlich, and E. Olson. 1988. Soil compaction: an economic model. Western J. Appl. For. 3: 20-22

Utzig, G. and M. Walmsley. 1988. Evaluation of soil degradation as a factor affecting forest productivity in British Columbia - a problem analysis Phase I. FRDA report 025. Pacific Forestry Centre. Victoria, B.C.

World Commission on Environment and Development. 1987. Our Common Future. Oxford University Press, New York. 